\title{
VICTIMS OF HUMAN TRAFFICKING IN THE SYSTEM OF SUPPORT AND PROTECTION IN SLOVAKIA

\author{
Magdaléna Horáková ${ }^{1}$, Barbara Pavlíková ${ }^{2}$
}

\begin{abstract}
:
Introduction: Studies aimed at supporting or protecting victims of human trafficking are rare, although this is a current issue with global overlap. The aim of this work is to identify the specifics of the victims who use the services of organizations under the Program for Support and Protection of Victims of Human Trafficking in Slovakia.

Methods: This research study was conducted using the method of content analysis of interviews with workers of organizations providing services under the Program for Support and Protection of Victims of Human Trafficking in Slovakia and documents issued by the Ministry of the Interior of the Slovak Republic (MoI SR) in 2010-2017.

Results: 210 victims of human trafficking included in the Program for Support and Protection of Victims of Human Trafficking were identified in the monitored period - 111 women and 99 men. From the perspective of origin, the area of the Eastern Slovakia was most prevalent. The demographic environment (village, district town, municipal city) did not play a significant role. The most common purpose of human trafficking was sexual exploitation and forced labour. There is no systematic approach in addressing the issue.

Conclusion: The creation of a pilot field social work program for victims of human trafficking using case management would help take into account the specificities of human trafficking victims. The program would allow for coordinating the services that might provide a solution to the problem of a trafficked person At the same time, by using case management, we can prevent the provision of the same services to the client by several organizations and increase the likelihood of a successful solution to the client's situation and work efficiency.
\end{abstract}

UDC Classification: 314.1; DOI: http://dx.doi.org/10.12955/cbup.v6.1220

Keywords: Human trafficking. Victim. Victims' assistance organizations. Research study.

\section{Introduction}

Jorge-Birol (2008) states that studies aimed at the support or protection of victims are rare. He also points out the fact that assistance and support are important for victims of any crime however, considering that victims of human trafficking are even more vulnerable, support and protection of them becomes inevitable, if not of vital importance. Trafficked persons are victims - and witnesses and are seen as sources of information for police investigations. Without their cooperation, it is often difficult to collect evidence and the application of domestic criminal law against traffickers becomes impossible. Protection of rights of trafficked persons and criminal investigation and prosecution of offenders should be understood as two complementary aspects (Orfano, 2010).

The first generally accepted definition of human trafficking was included in the Additional Protocol to the United Nations Convention against Transnational Organized Crime signed by the Slovak Republic on 12 December 2000 in Palermo. Within the meaning of Article 3(a) of the Protocol to Prevent, Suppress and Punish Trafficking of Persons, especially Women and Children, which the Government of the Slovak Republic agreed to sign with its Resolution No. 571 of 20 June 2001: "Trafficking in persons" shall mean the recruitment, transportation, transfer, harbouring or receipt of persons, by means of the threat or use of force or other forms of coercion, abduction, fraud, deception, the abuse of power or a position of vulnerability or of the giving or receiving of payments or benefits to achieve the consent of a person having control over another person, for the purpose of exploitation. Exploitation shall include sexual exploitation, forced labour or services, slavery or practices similar to slavery, servitude or the removal of organs" (UN, 2000, p. 2, UNODC, 2009). Human trafficking is also defined in Article 2 of the Directive 2011/36/EU. Slovak Criminal Code (Act No. 300/2005 Coll.) interprets the definition of human trafficking in Section 179.

The mechanism of human trafficking represents individual phases that victims go through. Each phase may represent a time period of varying lengths and have various characteristic features in every victim. These phases are recruitment, transportation, harbouring, receipt, coercion, abuse, rescue and reintegration (IOM, 2010).

\footnotetext{
${ }^{1}$ Faculty of Social Sciences and Health Care, Constantine The Philosopher University in Nitra, mhorakova@ukf.sk

${ }^{2}$ Faculty of Social Sciences and Health Care, Constantine The Philosopher University in Nitra, barbarapavlikova@gmail.com
} 
Purposes of trafficking can be divided into four basic groups: human trafficking for the purpose of sexual exploitation; human trafficking for the purpose of economic exploitation; human trafficking for the purpose of illegal adoption; and human trafficking for the purpose of illegal human organ trafficking (IOM, 2010).

The purpose of human trafficking as well as its process is different in every victim and should be viewed as such. Just as every victim is a unique human being, the way they cope with this difficult life event differs from victim to victim. Besides individual characteristics of a victim, an important role may be the purpose of their trafficking, the period of time spent in the trafficking cycle, the manner and process of rescue, the process of victim identification, the status of being a victim, participation in the prosecution of offenders, reintegration, etc. (Halásová, Valentíny, 2013 In Hardy, Briššáková, Mátel, 2013).

The assistance to victims falls under the internal Decree of the Ministry of the Interior of the Slovak Republic No. 180/2013 on ensuring the Program of Support and Protection for Victims of Human Trafficking. The system is rather complicated, and its practical application may bring problems. Also, the National Program for Combating Human Trafficking for years 2015 - 2018 was adopted. The pilot phase of the Program for Support and Protection of Victims of Human Trafficking was implemented under the National Action Plan for Combating Human Trafficking for years 2006 - 2007. It was updated and continued in the course of the following years under the National Program for Combating Human Trafficking for years 2008 - 2010 and 2011 - 2014. Currently, the National Program for Combating Human Trafficking for years 2015 - 2018 was adopted by the Resolution of the Government of the Slovak Republic No. 52 on 4 February 2015 and is in force (The National Program for Combating Human Trafficking, 2018). The Slovak government in its National Action Plan defined Slovakia as a country of origin of victims, but also as a transit country to an extent. Therefore, focusing solely on Slovak citizens trafficked abroad and in Slovakia represented a solution which did not make it possible to test the pilot program with a higher number of actual cases. This step also didn't allow for testing various modifications of residence status of a victim of human trafficking - a foreign national in the territory of the Slovak Republic (Šnajdrová, 2007). Modifications to the functioning of the Program for Support and Protection of Victims of Human Trafficking were laid down in the Decree of the Ministry of Interior of the Slovak Republic No. 47/2008 on Ensuring the Program of Support and Protection for Victims of Human Trafficking which defined the scope and quality of services provided to both domestic and transnational victims of human trafficking. Both categories of victims, as per the principle of equality and non-discrimination, should be provided with services reflecting their individual needs at the same level (MoI SR, 2011). For victims, the program will primarily mean that their isolation from the criminal environment; legalization of their stay in the territory of the Slovak Republic in case of a foreign national; assistance with their voluntary return to the Slovak Republic or the country of origin in case of a foreign national; social assistance; psychosocial counseling; psychotherapeutic services; legal advice; health care or re-qualifying courses will be ensured. If a victim decides to cooperate with law enforcement authorities, there is a possibility of providing complex care during the entire duration of criminal proceedings (The Program of Support and Protection for Victims of Human Trafficking, 2018).

The aim of this study is to identify the specificities of victims using the services of organizations under the Program of Support and Protection for Victims of Human trafficking. The answer to the question "What are the specificities of victims using the services of organizations under the Program of Support and Protection of Victims of Human Trafficking?" will be obtained using the selected methods.

\section{Data and methodology}

As already mentioned, studies aimed at the support or protection of victims are rare. The main sources of information related to this topic are reports from international organizations and international and national NGOs and their practical experience. The research study consists of a qualitative and a quantitative part. Its aim was to identify the specificities of victims using the services of organizations under the Program of Support and Protection of Victims of Human Trafficking in Slovakia.

The qualitative part of the data was obtained by means of a content analysis of semi-structured interviews conducted in 2014-2015 for the purpose of a dissertation. There were three organizations providing reintegration services under the Program of Support and Protection of Victims of Human 
Trafficking in Slovakia at the time: the Slovak Catholic Charity, the Slovak Crisis Centre DOTYK and, until 2014, IOM - International Organization for Migration. During the time the research study was under way, the focus of one of the organizations (IOM) was reduced to return assistance. Three experienced helping professionals from the organization were included in the research. As an IOM worker had a longer experience with assistance to trafficked persons, the authors considered that his opinion in relation to the issue was a contribution to the research findings and decided to analyse the interview with him.

Relevant statistical information was drawn from the Overviews of victims included in the Program of Support and Protection of Victims of Human Trafficking from 2010 - 2016 compiled by the MoI SR and the Situational report on combating human trafficking in the Slovak Republic of 2017.

\section{Results and Discussion}

According to the authors, the question "For whom are these services intended?" is of key importance when designing the services. It is important to know the target group, their characteristics and needs to be able to provide target-oriented and effective assistance. Therefore, we wanted to identify the specificities of victims using the services of organizations under the Program of Support and Protection of Victims of Human Trafficking. The prerequisite for using them is, pursuant to the Decree of the Ministry of Interior of the Slovak Republic No. 180/2013 on Ensuring the Program of Support and Protection for Victims of Human Trafficking, severing all contact with the criminal environment and expressing an interest in being included in the program by completing and signing an entry statement. Background materials are approved by a national coordinator who decides whether or not a person will be included in the program (MoI SR, 2012). Everyone may become a victim of human trafficking: men, women, and children, too. However, the intended focus was only on those trafficked persons who were using the services under the program.

Table 1 lists victims included in the Program of Support and Protection of Victims of Human Trafficking in years 2010-2017 by sex. From 2010, in which the same number of male and female victims was included, the number of female victims was prevalent until 2015. In recent years, the number of male victims of human trafficking has increased, in particular for the purpose of forced labour. The highest number of females (22) was included in 2014; the highest number of males used the services of the program both in 2015 and 2016, was 17 each year. Overall, 111 females and 99 males, i.e. 210 trafficked persons, were included in years 2010-2017. Our intention was to find out what distinguishes trafficked persons who do and do not use thepProgram.

Table 1 Number of victims included in the Program of Support and Protection of Victims in years
2010-2017 by sex
\begin{tabular}{|l|l|l|l|l|l|l|l|l|l|}
\hline & 2010 & 2011 & 2012 & 2013 & 2014 & 2015 & 2016 & 2017 & Total \\
\hline Female & 14 & 18 & 16 & 21 & 22 & 8 & 4 & 8 & 111 \\
\hline Male & 14 & 13 & 6 & 9 & 12 & 17 & 17 & 11 & 99 \\
\hline Total & 28 & 31 & 22 & 30 & 34 & 25 & 21 & 19 & 210 \\
\hline
\end{tabular}
$\begin{aligned} & \text { Source: Own processing based on the statistical data by MoI SR - Overview of victims included in } \\
& \text { the Program of Support and Protection of Victims of Human Trafficking from 2010-2016 and the } \\
& \text { Situational report on combating human trafficking in the Slovak Republic of 2017 }\end{aligned}$

The origin of victims included in the program was the Košice Region in 75 cases, the Prešov Region in 37 cases and the Banská Bystrica Region in 36 cases. From our point of view, the significance of the presented data lies in particular in the context of localization of helping organizations providing services to trafficked persons. Currently, these services are provided by the Slovak Crisis Centre Dotyk (the Trenčín Region) and the Slovak Catholic Charity (the Bratislava Region).

The highest number of persons by demographic environment reported their residence in a municipality. The term settlement is generally linked to marginalized groups of population (e.g. Roma). According to Rusnáková, Rochovská (2014), there is no exact definition of the term "Roma settlement". They note that they are ethnically homogenous settlements, segregated not only geographically, but also socially. Considering other research findings and estimates of experts on the issue, we believe that the piece of data related to settlements (6 persons) may be distorted or the persons may have permanent residence in a municipality and thus not further specify their answer and 
mark settlement. Demographic environment of victims was not included in the statistical data until 2011.

Table 2 Number of victims included in the Program of Support and Protection of Victims in years 2010-2017 by the origin of victims

\begin{tabular}{|l|l|l|l|l|l|l|l|l|l|}
\hline & 2010 & 2011 & 2012 & 2013 & 2014 & 2015 & 2016 & 2017 & Total \\
\hline Bratislava Region & 1 & 2 & 2 & 1 & 1 & 1 & 1 & 0 & 9 \\
\hline Žilina Region & 1 & 2 & 0 & 0 & 2 & 0 & 0 & 0 & 5 \\
\hline Nitra Region & 1 & 4 & 0 & 2 & 4 & 5 & 3 & 2 & 21 \\
\hline Trnava Region & 1 & 0 & 0 & 2 & 1 & 2 & 1 & 0 & 7 \\
\hline Trenčín Region & 1 & 5 & 0 & 0 & 1 & 0 & 0 & 0 & 7 \\
\hline Banská Bystrica Region & 3 & 5 & 5 & 5 & 5 & 5 & 5 & 3 & 36 \\
\hline Košice Region & 11 & 7 & 8 & 15 & 13 & 8 & 5 & 8 & 75 \\
\hline Prešov Region & 9 & 5 & 5 & 3 & 5 & 3 & 2 & 5 & 37 \\
\hline Foreign country & 0 & 1 & 2 & 2 & 0 & 1 & 4 & 1 & 11 \\
\hline Not specified & 0 & 0 & 0 & 0 & 2 & 0 & 0 & 0 & 2 \\
\hline Total & 28 & 31 & 22 & 30 & 34 & 25 & 21 & 19 & 210 \\
\hline
\end{tabular}

Source: Own processing based on the statistical data by MoI SR - Overview of victims included in the Program of Support and Protection of Victims of Human Trafficking from 2010-2016 and the Situational report on combating human trafficking in the Slovak Republic of 2017

Table 3 Number of victims included in the Program of Support and Protection of Victims in years 2011-2017 by demographic environment

\begin{tabular}{|l|l|l|l|l|l|l|l|l|l|}
\hline & 2010 & 2011 & 2012 & 2013 & 2014 & 2015 & 2016 & 2017 & Total \\
\hline Regional capital & not specified & 10 & 7 & 3 & 9 & 0 & 2 & 5 & 36 \\
\hline District town & not specified & 9 & 8 & 4 & 8 & 5 & 2 & 2 & 38 \\
\hline Town & not specified & 7 & 2 & 7 & 4 & 6 & 5 & 4 & 35 \\
\hline Municipality & not specified & 3 & 4 & 14 & 9 & 12 & 11 & 7 & 60 \\
\hline Settlement & not specified & 1 & 1 & 1 & 2 & 2 & 0 & 0 & 7 \\
\hline Unknown/Other & not specified & 1 & 0 & 1 & 2 & 0 & 1 & 1 & 6 \\
\hline Total & not specified & 31 & 22 & 30 & 34 & 25 & 21 & 19 & 182 \\
\hline
\end{tabular}

Source: Own processing based on the statistical data by MoI SR - Overview of victims included in the Program of Support and Protection of Victims of Human Trafficking from 2010-2016 and the Situational report on combating human trafficking in the Slovak Republic of 2017

Table 4 Number of victims included in the Program of Support and Protection of Victims in years 2010-2017 by level of education

\begin{tabular}{|l|l|l|l|l|l|l|l|l|l|}
\hline & 2010 & 2011 & 2012 & 2013 & 2014 & 2015 & 2016 & 2017 & Total \\
\hline None & 0 & 3 & 2 & 3 & 0 & 0 & 0 & 1 & 9 \\
\hline Primary & 15 & 10 & 11 & 14 & 15 & 8 & 9 & 7 & 89 \\
\hline Special primary school & 4 & 4 & 2 & 3 & 7 & 5 & 0 & 3 & 28 \\
\hline Lower secondary & 6 & 5 & 3 & 5 & 8 & 11 & 6 & 5 & 49 \\
\hline Upper secondary & 2 & 6 & 2 & 3 & 3 & 1 & 5 & 3 & 25 \\
\hline University & 1 & 3 & 1 & 0 & 0 & 0 & 1 & 0 & 6 \\
\hline Not specified & 0 & 0 & 1 & 2 & 1 & 0 & 0 & 0 & 4 \\
\hline Total & 28 & 31 & 22 & 30 & 34 & 25 & 21 & 19 & 210 \\
\hline
\end{tabular}

Source: Own processing based on the statistical data by MoI SR - Overview of victims included in the Program of Support and Protection of Victims of Human Trafficking from 2010-2016 and the Situational report on combating human trafficking in the Slovak Republic of 2017 
Of the total number of 210 trafficked persons included in the Program in years 2010-2017, as many as 89 reported a primary education level, 28 visited a special primary school and 9 did not complete their compulsory education. This amounts to 126 persons, which represents more than a half of the total number.

The purposes of exploitation were primarily forced labour (86 persons) and sexual exploitation (77 persons). In 2016, statistics of MoI SR listed, besides data presented in Table 5, specific cases where one person was exploited for the purpose of forced labour and forced begging at the same time, one person for the purpose of forced labour and forced marriage and one person for the purpose of sexual exploitation, forced labour and forced marriage. There could have been more forms of exploitation present in one person in other years; however, they were not specified. Worth noting are also forced marriage (27 persons) and forced begging ( 26 persons), in particular in view of the provision of the Act No. 300/2005 Coll. (the Criminal Code) discussing also the purpose of trafficking. Begging was included and other purposes, such as forced marriage and exploitation for the purpose of engaging in criminal activities (Halcín, 2013).

Table 5 Number of victims included in the Program of Support and Protection of Victims in years 2010-2017 by the purpose of exploitation

\begin{tabular}{|l|l|l|l|l|l|l|l|l|l|}
\hline & 2010 & 2011 & 2012 & 2013 & 2014 & 2015 & 2016 & 2017 & Total \\
\hline Sexual exploitation & 10 & 12 & 15 & 15 & 13 & 2 & 3 & 7 & 77 \\
\hline Pornographic industry & 1 & 0 & 0 & 0 & 0 & 0 & 0 & 0 & 1 \\
\hline Forced labour & 11 & 12 & 3 & 10 & 12 & 17 & 12 & 9 & 86 \\
\hline Forced begging & 2 & 2 & 5 & 2 & 6 & 5 & 2 & 2 & 26 \\
\hline Economic exploitation & 4 & 6 & 0 & 0 & 0 & 0 & 0 & 0 & 10 \\
\hline Forced marriage & 0 & 2 & 3 & 7 & 9 & 4 & 1 & 1 & 27 \\
\hline Forced criminality & 0 & 4 & 0 & 0 & 1 & 1 & 0 & 0 & 6 \\
\hline $\begin{array}{l}\text { Slavery/Practices } \\
\text { similar to slavery }\end{array}$ & 0 & 0 & 0 & 0 & 1 & 0 & 0 & 0 & 1 \\
\hline Other form & 0 & 0 & 0 & 1 & 0 & 0 & 0 & 0 & 1 \\
\hline Total & 28 & 38 & 26 & 35 & 42 & 29 & 18 & 19 & 235 \\
\hline
\end{tabular}

Source: Own processing based on the statistical data by MoI SR - Overview of victims included in the Program of Support and Protection of Victims of Human Trafficking from 2010-2016 and the Situational report on combating human trafficking in the Slovak Republic of 2017

Qualitative data was obtained using a content analysis of semi-structured interviews with workers of organizations providing care to victims of human trafficking under the Program of Support and Protection of Victims of Human Trafficking. The aim was to identify the specificities of victims included in the program from the organization workers' perspective. In a study of 2015, several categories were identified. The first category was "Belonging to socially disadvantaged or marginal groups", where young adults brought up in children's homes, the unemployed, persons in material need, persons with low level of education, socially more vulnerable persons and persons abusing substances were included. The second category was ethnic groups (Roma). The names of the first two categories were selected based on categories used by EUROPOL (2011) for informing experts on risk groups. Other specificities from the perspective of workers resulting from their practical experience with target groups were the absence of a safety net, aversion to experts, the absence of skills, unwillingness to change one's life, unwillingness to find a job and to return to a natural environment, with Roma communities being defined as a natural environment.

Services of organizations under the Program of Support and Protection of Victims of Human Trafficking in Slovakia aimed at reintegration of trafficked persons are provided primarily to adult nationals of the Slovak Republic; children and foreign nationals are included in rare cases. Therefore, in our opinion, the practical experience of workers with these groups is limited to a handful of cases. For trafficked persons - foreign nationals and children - there are other specific areas in view of their legal status that should be taken into account. That's why the focus was on the most numerous group of persons in the program - adult nationals of the Slovak Republic - when proposing solutions. 
Demographic data from the statistics of MoI SR on victims included in the Program of Support and Protection of Victims of Human Trafficking show that the origin of victims and localization of services for them is different. Surtees (2008) states that many services intended for trafficked persons are nowadays concentrated around the country's capital or larger cities. According to her, that's why persons are often required, at least initially, to stay in the environment of an organization (or within its reach) in order to use its services. In case of a concealed accommodation (in remote towns), there is a risk of a limited access for victims to this type of services. The situation is similar in the Slovak Republic.

Workers of organizations pointed out that, in many cases, persons return to their natural environment and use the services of organizations only for a certain period of time. According to them, many persons included in the Program are Roma people with their natural environment in Roma communities.

Surtees (2008) claims that reintegration services should be available to victims regardless of whether they decide to use accommodation services offered by organizations, arranged accommodation, or prefer to return home to their family and community.

From our perspective, the program settings should flexibly respond to the needs of clients who use it seeking effectiveness in provided services.

According to statistical data, most persons included in the program come from the Košice Region (75), the Prešov Region (37) and the Banská Bystrica Region (36).

According to the Research Demographic Centre (In Návrh koncepcie., 2015), the largest concentration of Roma population is in these regions (in the Prešov Region, followed by the Košice and the Banská Bystrica Region).

Malangone and Stránska (2011) note that information on the number of Roma victims of human trafficking (as well as other data on Roma in Slovakia) are taken only from unofficial sources. The main reason for this, as they see it, is the generally accepted interpretation of the legislation in force under which it is unlawful to maintain records on data revealing the person's ethnic origin.

This is imposed by the Personal Data Protection Act (2015), also governing a number of exceptions from this rule. Examples of this include the purposes of “(...) the provision of social services, implementing the measures of social and legal protection of children or social guardianship or the provision of assistance in material need (...)". Based on these arguments, Malangone and Stránska (2011) claim that the interpretation that it is not possible to collect data is rather an issue of practice than one of legislation.

According to estimates of the Police Force of the Slovak Republic, over $60 \%$ of victims of human trafficking come from marginalized Roma communities (Lajčáková, 2013). Lajčáková (2013) claims that these numbers are only insignificantly reflected in the state's approach to combating human trafficking, while also expressing an opinion that the responsibility is transferred to a nongovernmental sector. According to her, the sector does not dispose of sufficient financial and personal capacities for solving the issue.

Surtees (2008) introduces so-called "difficult cases" identified by organizations working on reintegration which their workers encounter in practice. These include the following: - dependent children or family members, - health disadvantages, - substance abuse, - mental health issues, - severe health condition, - the absence of identity documents or legal status, - safety issues, - the absence of family support, - social marginalization, - past experience with violence. Listed cases correspond to the findings of research conducted in our country.

EUROPOL (2011) defined criteria for individual areas (e.g. age, sex, level of education, behavioural attitudes, place of residence, belonging to marginal and ethnic groups) which indicate the presumption that a person belongs to a risk group in the context of human trafficking.

In our opinion, the purpose of exploitation, sex, ethnicity, origin, belonging to marginalized groups, and other mentioned specificities need to be taken into account in the process of reintegration care, as they may determine the selection of specialized assistance based on the victim's individual needs. 


\section{Conclusion}

In the provision of reintegration care in Slovakia, there is from our perspective, room for solutions which would facilitate its effective functioning. One solution is the creation of a pilot field social work program for victims of human trafficking in localities of their origin. An important element, with regard to the multidisciplinary nature of the issue, would be the use of the case management method. Dosoudilová (2008) states that the use of the case management method within the field social work originates in the need of coordinating the services entering the process of addressing the issue of trafficked person. In addition, the use of case management may prevent the provision of identical services to a client by several organizations and increase the probability of a successful solution to a client's issue and work efficiency. The work of Roma mediators would be used in order to mediate contact with victims in the community. Maintaining gender equality and varied ethnicity of workers have proved successful in practice so far. The work of field social workers would be coordinated by regional centres (primarily established in the Košice, the Prešov and the Banská Bystrica Region with regard to the origin of victims included in years 2010-2017). Their tasks, besides coordination, would include monitoring, screening, control, evaluation and training of service workers, the creation of work manuals and informational and educational materials. In addition, the centres could conduct supervision meetings for service workers (various professions would be represented due to a multidisciplinary nature) as well as administer their activities for the needs of MoI SR. The powers in relation to including the victims in the program are held by a relatively small group of people separated from practice without the condition of being educated in the field of social work (a national coordinator has the competence for including/excluding a victim; individual assistance plans are approved by the Information Centre for Combating Human Trafficking and Crime Prevention). Therefore, practical issues related to direct work with a client (an individual assistance plan) would be decided directly by the workers of the proposed regional centres. At the same time, a control mechanism of work of regional centres and field social workers should be set up which should be managed by a group of experts on human trafficking complemented by experts in other fields. The issue of care for trafficked persons requires systemic solutions in every country. In our opinion, the effective reintegration care would benefit from establishing minimum standards for the provision of services that would take into account the specificities of recipients of the service in the territory of the Slovak Republic. These standards would be established by both practical and theoretical experts in various fields (social workers, psychologists, legal experts, physicians, etc.). With regard to research findings, we perceived the importance of involving ethnic group members in establishing these standards, as their perspective may be a contribution. Čámský et al. (2008) notes that frequent assessment of needs of population groups is a common practice in European countries and in the U.S. The point of the investigation is maximizing the efficiency of the provided services or identifying the services which are not available in a given locality and need to be implemented.

\section{References}

Č́mský, P. a kol. 2008. Manuál pro tvorbu a zavádění standardů kvality poskytovaných sociálních služeb. Praha: Centrum sociálních služeb Praha. 2008. 152 p.

Dousilová, K. 2008. Aplikace case managementu v terénní sociální práci. In Janoušková, K., Nendělníková, D. (Eds). Profesní dovednosti terénních sociálních pracovníků. Sborník studijních textů pro terénní sociální pracovníky. Ostrava: Ostravská univerzita v Ostravě, Zdravotně sociální fakulta, katedra sociální práce, 2008. ISBN 978-80-7368-504-1. p. 323329.

EUROPOL. 2011. Trafficking in Human Beings in the European Union. Hague, 2011. 15 p.

Halásová, M., Valentíny, M. 2013. Problematika obetí obchodovania s l’ud'mi v Slovenskej republike. In Hardy, M., Briššáková, J., Matel, A. Rodinná politika na Slovensku a v Európskej únii. Zborník z medzinárodnej vedecko-odbornej konferencie. [CD-ROM] Bratislava: VŠZaSP sv. Alžbety, 2013. pp 307-318 ISBN 978- 80-8132-084-2.

Halcín, J. 2013. Situácia v oblasti obchodovania s l'ud’mi z pohl’adu Ministerstva vnútra Slovenskej republiky. In Halásová, M., Chovancová, K., Valentíny, M. Obchodovanie s l'ud’mi- prevencia, výskum, prax. Zborník z vedeckoodbornej konferencie [CD-ROM]. Nitra: Združenie STORM, KSPaSV UKF v Nitre, 2013. pp 5 - 10 ISBN 978-80-970667-8-0.

IOM. 2010. Základné informácie o problematike obchodovania s l’ud’mi. Bratislava: IOM. 2010. 101 p. ISBN 978-80-8950606-4.

Jorge-Birol, A. P. 2008. Empowering Victims of Human Trafficking: the Role of Support, Assistance and Protection Policies. [online]. [accessed 19 April 2018]. Available at:

<http://www.humsec.eu/cms/fileadmin/user_upload/humsec/Journal/Pedra.pdf〉. 
Lajčáková, J. 2013. Správa občianskej spoločnosti o implementácii stratégie Slovenskej republiky pre integráciu Rómov do roku 2020 a revidovaného akčného plánu dekády na Slovensku. Budapešt': Decade of Roma Inclusion Secretariat Foundation, 2013. 90 p. ISSN 2064-0765.

Malangole A., Stránska, T. 2011. Správa Slovensko: Asistencia a reintegrácia detských obetí obchodovania: podpora a hodnotenie najlepších postupov v krajinách pôvodu a ciel’ových krajinách (ARECHIVIC), Čast' 1: Analýza politík, inštitucionálneho a právneho systému Centre for the study of Democracy, People in need, 2011. $60 \mathrm{p}$.

MV SR. 2012. Metodická pomôcka zameraná na postup všetkých zainteresovaných subjektov v prípadoch poskytovania pomoci obetiam obchodovania s l'ud'mi s osobitným zameraním na špecifiká postupu v prípade obchodovania s l'ud'mi cudzincov, ako aj v prípade maloletých obetí obchodovania s l'ud'mi. Košice: MV SR. 2012. 16 p.

MV SR. Národný program boja proti obchodovaniu s l'ud'mi na roky 2011-2014. Bratislava: MV SR. 2011. 84 p.

MV SR. 2009. Prehl'ad o obetiach zaradených do Programu podpory a ochrany obetí obchodovania s l'ud'mi za rok 2010. 11 p. [online]. [cit. 2015-03-30]. Available at: 〈http://www.minv.sk/?program_podpory_a_ochrany_obeti>.

MV SR. 2012. Prehl'ad o obetiach zaradených do Programu podpory a ochrany obetí obchodovania s l'ud'mi za rok 2011. 19 p. [online]. [cit. 2015-03-30]. Available at: 〈http://www.minv.sk/?program_podpory_a_ochrany_obeti>.

MV SR. 2013. Prehl'ad o obetiach zaradených do Programu podpory a ochrany obetí obchodovania s l'ud'mi za rok 2012. 14 p. [online]. [cit. 2015-03-30]. Available at: 〈http://www.minv.sk/?program_podpory_a_ochrany_obeti>.

MV SR. 2014. Prehl'ad o obetiach zaradených do Programu podpory a ochrany obetí obchodovania s l'ud'mi za rok 2013. 2014. 29 p. [online]. [cit. 2015-03-30]. Available at: <http://www.minv.sk/?program_podpory_a_ochrany_obeti>.

MV SR. 2015. Prehl'ad o obetiach zaradených do Programu podpory a ochrany obetí obchodovania s l'ud'mi za rok 2014. 2015. 35 p. [online]. [cit. 2015-03-30]. Available at: <http://www.minv.sk/?program_podpory_a_ochrany_obeti>.

MV SR. 2016. Prehl'ad o obetiach zaradených do Programu podpory a ochrany obetí obchodovania s l'ud'mi za rok 2015. 2016. 35 p. [online]. [cit. 2015-03-30]. Available at: 〈http://www.minv.sk/?program_podpory_a_ochrany_obeti>.

MV SR. 2017. Prehl'ad o obetiach zaradených do Programu podpory a ochrany obetí obchodovania s l'ud'mi za rok 2016. 2017. 27 p. [online]. [cit. 2015-03-30]. Available at: <http://www.minv.sk/?program_podpory_a_ochrany_obeti>.

MV SR. 2018. Situačná správa pre oblast' boja proti obchodovaniu s l’ud'mi v slovenskej republike za rok 2017. 2018. 47 p. [online]. [cit. 2015-03-30]. Available at: 〈http://www.minv.sk/?program_podpory_a_ochrany_obeti〉.

Návrh koncepcie výchovy a vzdelávania rómskych detí a žiakov vrátane rozvoja stredoškolského a vysokoškolského vzdelávania. [online]. [cit. 2015-03-20]. Available at: 〈https://www.minedu.sk/data/att/944.pdf>

Orfano, I. 2010. Príručka pro rozvoj mezinárodního referenčního mechanismu pro osoby obchodované v Evropě. MRM EU. Odbor pro rovné př́ležitosti - předsednictví Itálie v Radě EU, Mezinárodní centrum pro rozvoj migrační politiky (ICMPD), 2010. 167 p. ISBN 978-3-900411-63-3.

Rusnáková, J., Rochovská, A. 2014. Segregácia obyvatel’ov marginalizovaných rómskych komunít, chudoba a znevýhodnenia súvisiace s priestorovým vylúčením. In Geographia Cassoviensis. ISSN 1337-6748, 2014, roč. VIII, č. 2. pp $162-172$.

Šnajdrová, H. 2007. Program podpory a ochrany obětí obchodování s lidmi na Slovensku. Bratislava: UNODC. 2007. 34 p. Surtees, R. 2008. Re/integration of trafficked persons: how can our work be more effective. Vienna: NEXUS Institute to Combat Human Trafficking, 2008. 49 p. ISBN 978-90-5130-635-4.

The Act No. 122/2013 Coll. on Protection of Personal Data and on Changing and Amending of other acts, resulting from amendments and additions executed by the Act. No. 84/2014 Coll. [online]. [cit. 2015-06-12]. Available at: <http://www.dataprotection.gov.sk/uoou/sites/default/files/kcfinder/files/136_2014.pdf>.

The Act No. 300/2005 Coll. (the Criminal Code) [online]. [accessed 31 March 2018]. Available at: https://www.slov-lex.sk/pravne-predpisy/SK/ZZ/2005/300/20180101

The Decree of the Ministry of Interior of the Slovak Republic No. 180/2013 on Ensuring the Program of Support and Protection for Victims of Human Trafficking.

The Directive 2011/36/EU of the European Parliament and of the Council of 5 April 2011 on preventing and combating trafficking in human beings and protecting its victims, and replacing Council Framework Decision 2002/629/JHA

The Program of Support and Protection of Victims of Human Trafficking. [online]. [accessed 19 April 2018]. Available at: <http://www.minv.sk/?program_podpory_a_ochrany_obeti>.

UN General Assembly. Protocol to Prevent, Suppress and Punish Trafficking inPersons, Especially Women and Children, Supplementing the United Nations Convention against Transnational Organized Crime, 15 November 2000. [online]. [accessed 29 March 2018]. Available at: <http://www.unhcr.org/refworld/docid/4720706c0.html>.

UNODC. 2009. Combating trafficking in persons. Vienna: UNODC. 2009. 121 p. ISBN:978-92-1-133665-8. 